University of Nebraska - Lincoln

DigitalCommons@University of Nebraska - Lincoln

$5-1-1991$

\title{
An Agenda for Research on Economic Education in Colleges and Universities
}

William Becker

Indiana University, beckerw@iu.edu

Robert Highsmith

Joint Council on Economic Education, New York, NY

Peter Kennedy

Simon Fraser University, Burnaby, B.C. Canada

WILLIAM WALSTAD

University of Nebraska-Lincoln, wwalstad1@unl.edu

Follow this and additional works at: https://digitalcommons.unl.edu/cbafacpub

Part of the Business Commons

Becker, William; Highsmith, Robert; Kennedy, Peter; and WALSTAD, WILLIAM, "An Agenda for Research on Economic Education in Colleges and Universities" (1991). College of Business Faculty Publications. 33. https://digitalcommons.unl.edu/cbafacpub/33

This Article is brought to you for free and open access by the Business, College of at DigitalCommons@University of Nebraska - Lincoln. It has been accepted for inclusion in College of Business Faculty Publications by an authorized administrator of DigitalCommons@University of Nebraska - Lincoln. 


\title{
An Agenda for Research on Economic Education in Colleges and Universities
}

\author{
By William Becker, Robert Highsmith, Peter Kennedy, \\ AND William Walstad*
}

The quantity of research on economic education at the college and university level declined during the past decade. In the 1980-90 period, the number of researchrelated articles on economics instruction in higher education fell by about 17 percent from the number published during the 1969-79 period. A possible reason for this reduction may have been the publication of a review of research on economic education at the college and university level by John Siegfried and Rendigs Fels (1979). This extensive survey may have inadvertently led researchers to believe that most of the major topics at this level had been studied and that further research would not yield insights. Another reason could have been the success of the Joint Council on Economic Education in directing resources to precollege issues.

Whatever the reasons for the college-level decline, it is disturbing because we think the teaching of economics in colleges and universities can be improved by research on what influences the delivery and the effectiveness of instruction. In our view, research on economic education at the postsecondary level should be directed to three major areas. First, the multiple outputs from learning economics need to be defined, measured, and investigated so that a fuller range of benefits from studying economics can be incorporated into decisions about courses and degree programs. Second, more emphasis should be placed on the analysis

\footnotetext{
*Indiana University, Bloomington, IN 47405; Joint Council on Economic Education, New York, NY 10016; Simon Fraser University, Burnaby, B.C. Canada V5A 1S6; and University of Nebraska, Lincoln, NE 685880402 , respectively. This paper is an abridged version of a forthcoming Journal of Economic Education (Summer 1991) article. Constructive criticism on earlier drafts was provided by W. Lee Hansen, John Siegfried, and Michael Watts.
}

of the economics major, as distinct from individual courses, to enhance the structuring of programs. Third, the replication of earlier research is required to determine the extent to which conclusions drawn from those studies still hold and to relate those findings to new developments.

\section{Multiple Outputs}

College economics courses may contribute more to student development than can be measured by scores on a cognitive test. W. Lee Hansen (1986), for example, described five "proficiencies" that he thinks students should be able to demonstrate from majoring in economics (i.e., gaining access to existing knowledge, displaying command of existing knowledge, displaying the ability to draw out existing knowledge, utilizing existing knowledge to explore issues, and creating new knowledge). This demonstration would be difficult in a multiple-choice testing framework.

Recognition of the multiple outputs from studying economics has not gone unnoticed in the research literature in economic education. Hansen, Allen Kelley, and Burton Weisbrod (1970) discussed the need for more research on how desired outcomes and how the distribution of benefits from teaching differ among students. Judith Yates (1978) complained that our research horizons were too narrow because of our focus on easily measured outputs. Eric Hanushek (1979; 1986) described the importance of joint products in the educational process, and, in particular, faulted researchers in economic education for their singular emphasis on multiple-choice tests. Despite the widespread knowledge that there are multiple outputs from teaching, few studies in economic education have incorporated this fact. 
The problem of deciding how to value outcomes also must be considered. For example, William Becker, William Greene, and Sherwin Rosen (1990) argue against the use of change-score models in economic education research because these models ignore the fact that the market for new graduates does not place a value on student learning as much as it values the final level of accomplishment. They assert that the normative beliefs of an instructor or entire faculty about the importance of given intellectual skills is elusive without reference to what employers are paying for the bundle of skills embodied in the college graduate, and what they desire from the graduate. Becker and William Walstad (1990) also show that data loss from pretest to posttest may pose problems for assessing value added.

Debates on problems associated with the value added by education make clear that research on a wider coverage of outcomes from instruction will not be easy to conduct. Each output must first be clearly identified and accurately measured. A consensus also needs to be reached among researchers about what is required to assess each outcome. The scope of research work then must be broadened to include an array of outcomes, if they can be measured and are considered to be important.

Several research topics to be addressed in the context of multiple outputs seem to have particular relevance in considering inputs as well. First, what is the role of basic skills (i.e., reading, writing, computing, and mathematics) in economics courses? For example, do students who are asked to use mathematics in their courses gain a better understanding of economics than students who use limited mathematics? Conversely, does the study of economics significantly improve mathematics skills? It seems reasonable to think that basic mathematics skills are both an input for economics learning and an output from economics learning, but at present we have limited empirical data on these possible relationships. Better knowledge of the interaction between basic skills as inputs and outputs from economics instruction would be valuable for identifying prerequisites for courses.
A second subject for study is the relative merits of fixed-response (multiple choice) and constructed-response (essay or short answer) tests for measuring student achievement in economics. Although the shortcomings of fixed-response tests are well known, the benefits of reliable and valid measures of a multiple-choice-type test for evaluation and research may not be outweighed by the negatives. What is needed is further exploration of the relationship between student performance on fixed-response vs. constructed-response tests. Do the different tests capture different dimensions of student performance, or are they measuring essentially the same dimension? The value of fixed-response vs. constructed-response measures is debated among faculty members. There is a literature on the topic in other fields (see Hunter Breland et al., 1987), but the issue has not been thoroughly investigated in economics.

A third topic is research on learning retention. Research typically measures cognitive outcomes during an economics course. With the notable exception of Phillip Saunders (1980), no extensive research exists on the lasting effects from economics coursework because longitudinal data typically are not available. These data should be collected to investigate what students retain $\mathrm{X}$ years after completing coursework and a major in economics. Presumably there is a host of factors that explain retention from a course, a series of courses, or from the major. We also suspect that the level of retention differs across the multiple outputs.

A fourth area for research is the effect of instructors on student outcomes. The target for the work would be the identification of the attributes that exemplary teachers of economics develop as they accumulate more classroom experience; knowledge of the characteristics of good teaching should enable new instructors to shorten the time it takes to become better teachers. We also suspect that exemplary teachers, consciously or unconsciously, strongly affect more than one dimension of student development. A starting point for this research would be to survey economists who have won awards for 
excellence in teaching. These findings could be compared to results from similar surveys in other disciplines, or to the extensive research on student evaluation of instruction in economics. Psychologists have also studied differences in the characteristics of "expert" and "novice" approaches to problem solving, and research of this type might have application to economics teaching.

\section{The Economics Major}

Although a few studies (for example, Siegfried and Jennie Raymond, 1984), have examined the economics major, more can be learned about the demand curve for course enrollments and majors. One question yet to be answered, for example, is why students take courses and/or major in economics. A related query is why students elect certain courses in economics when majoring in the subject. Factors such as course difficulty, instructor or department reputation, recommendations of peers, preparation for graduate school, or personal characteristics might be included in a list of factors influencing course selection or the decision to major in economics.

There are many alternative routes to a major in economics; for example, majors may have a business or social science orientation with emphasis on either applied or theoretical work. We need to know the benefits and drawbacks of these alternatives. In addition, the claim is often made that training in economics is central to an understanding of the complexities of the world. It is not clear to what extent this claim is justified relative to those of other social sciences or areas of study. How do economics majors evaluate their educational experience compared with students majoring in business or other social sciences?

Addressing these concerns will initially involve some survey work. The questions we are posing, however, are broader and focus on assessing the relative value of an education in economics as perceived by students who are taking classes or by those who have completed a course of study. Expansion of the data sources will be necessary for some of the evaluations. For example, alumni records from colleges and universities might be exploited for examining the performance of students after graduation or for evaluating performance differences across alternative economics majors. Moreover, "successful persons" (top corporate executives, government officials, or community leaders) who have majored in economics could be contacted and asked how majoring in economics contributed to their success. Despite the potential for sample selection problems, a follow-up survey of alumni or the most successful alumni might identify features of economics that should be emphasized by departments.

\section{Replications}

Fundamental to sound research is the ability to replicate results. Economic education is sufficiently mature as a research area that some of the "accepted" results should be reexamined. Replication should not be mere duplication; it should also provide opportunities to extend previous work in new directions.

The questions that should be reexamined are numerous. One topic studied in the 1970's was how high school preparation in economics affects performance in the college principles of economics classes or the decision to select economics as a major (see Saunders, 1970). Since those studies were conducted, many changes have occurred in high school courses. A variety of "economics" courses are being mandated by states, and there is now an Advanced Placement course in economics (Stephen Buckles and John Morton, 1988). There are also more instructional materials available, and teachers may be better prepared to teach economics. These changes suggest that college students with experience in high school economics may have advantages that bear on their placement and treatment in college-level economics courses.

A second topic is the effects of class size. Although students tend to dislike large classes, many studies of introductory courses have found that class size has little influence on multiple-choice test scores once class size rises above a threshold level (David 
Williams et al., 1985). Henry Raimondo, Louis Esposito, and Irving Gershenberg (1990), however, found that large classes at the intermediate level can be detrimental in some areas of economics. The work of David Card and Alan Krueger (1990) suggests that class size, as well as other expenditure variables, may affect the financial returns from education. The critical role of class size on the multiple outputs of economic education needs to be established.

A third topic, often debated in economics departments, is the optimum order in which courses are taken. For instance, does it matter if students take the microeconomics course before the macroeconomics course? Possibly because of differences in output measures and research design, studies by John Fizel and Jerry Johnson (1986) and James McCoy, David Brasfield, and Martin Milkman (1989) suggest conflicting answers to such questions. Related to these replications would be studies that address possible efficiency gains from condensing the two-semester principles courses into a onesemester course.

A fourth topic, controversial in many larger economics departments, is the increasing employment of graduate student instructors for whom English is a second language. Complaints have been raised by students, parents, and legislators about whether undergraduate students are able to perform as well with nonnative Englishspeaking instructors as they are able to do with native English-speaking instructors. Michael Watts and Gerald Lynch (1989) found that students with instructors for whom English was a second language performed less well than students with instructors for whom English was a first language. If this finding is supported by studies at other institutions, steps may be needed to upgrade the language and teaching skills of these potential instructors before they are permitted to teach.

A fifth topic is how student and instructor differences affect student outcomes and instructor performance. Studies have been done on the relationship between teaching style and learning styles. Replication of previous work and further study along these lines may identify ways the teaching of economics can be structured to achieve a better match between the teaching styles of instructors and learning styles of students. Also, we need to know more about the role of gender, race, ethnic background, socioeconomic status, and general ability because they are likely to affect the multiple outcomes from economics instruction and related issues such as the decision to major in economics.

A sixth topic is the role of new technologies. In the 1960's, televised lectures were touted as a means to meet college enrollment demands. Mainframe computers were considered in the 1970's to add variety to classroom lectures and to manage instruction. The 1980's witnessed the introduction of the microcomputer and improvement in videotape technology. Yet few of these innovations got beyond the experimental stage. The applicability of research on past innovations to current innovations is of questionable value. We know little about the cost effectiveness of newer technologies on student performance in a course or in the major.

\section{Concluding Comments}

We urge researchers in economic education to mobilize in this decade, as they did in the 1970's, to advance our understanding of the teaching of economics at the postsecondary level. The quality of work in economic education, at all levels, is steadily improving and researchers are finding more imaginative ways of addressing problems both old and new. Although by publishing this agenda we hope to influence the direction of future research in this area, we hope also that researchers will feel free to attack the problems they perceive to be important, in the ways they see fitting.

We recognize that some of our current agenda, in particular the part relating to multiple outputs, involves work requiring considerable resources and the coordination/interaction of several researchers. The AEA Committee on Economic Education (CEE) and the Joint Council on Economic Education (JCEE) must be encouraged to 
develop a "social infrastructure" that allows individual researchers to tackle this agenda in an efficient manner. In this regard, we offer two final recommendations.

If multiple outputs are to play a prominent role in future research, individual researchers should be given guidance on what outputs are thought to be relevant, and how they are to be measured. We recommend that the JCEE, in cooperation with the CEE, solicit position papers on output measures from a range of scholars in a variety of disciplines, convene a conference to debate this issue, obtain a consensus on the outputs that should be used for assessment purposes, and develop instrumentation and data bases for these new output measures.

Much of the agenda overlaps extensively with research in education and in other disciplines. Economics is not the only discipline with an "education" division, and many learning concepts described in the education literature could provide fertile ground for research in economic education. Researchers in economic education should become more conversant with this education literature. To facilitate this, we recommend that the JCEE and the CEE commission surveys of relevant dimensions of this literature, with particular emphasis on how results in this literature relate to results in the economic education literature.

\section{REFERENCES}

Becker, William and Walstad, William, "Data Loss from Pretest to Posttest As a Sample Selection Problem," Review of Economics and Statistics, February 1990, 72, 184-88.

, Greene, William and Rosen, Sherwin,

"Research on High School Economic Education," American Economic Review Proceedings, May 1990, 80, 14-22.

Breland, Hunter et al., Assessing Writing Skills, New York: College Entrance Examination Board, 1987.

$\rightarrow$ Buckles, Stephen and Morton, John, "The Effects of Advanced Placement on College Introductory Economics Courses," Amer- $\rightarrow$ ican Economic Review Proceedings, May $1988,78,263-68$.
Card, David and Krueger, Alan, "Does School Quality Matter? Returns to Education and the Characteristics of Public Schools in the United States," NBER Working Paper No. 3358, 1990.

Fizel, John and Johnson, Jerry, "The Effects of Macro/Micro Course Sequencing on Learning and Attitudes in Principles of Economics," Journal of Economic Education, Spring 1986, 17, 87-98.

$\rightarrow$ Hansen, W. Lee, "What Knowledge Is Most Worth Knowing-For Economics Majors," American Economic Review Proceedings, May 1986, 76, 149-52.

, Kelley, Allen C. and Weisbrod, Burton, "Economic Efficiency and the Distribution of Benefits from College Instruction," American Economic Review Proceedings, May 1970, 60, 364-69.

$\rightarrow$ Hanushek, Eric A., "Conceptual and Empirical Issues in the Estimation of Educational Production Functions," Journal of Human Resources, Summer 1979, 14, 351-88.

"The Economics of Schooling," Journal of Economic Literature, September 1986, 24, 1141-77.

McCoy, James, Brasfield, David and Milkman, Martin, "Course, Sequence and Student Performance in Principles of Economics," paper presented at the Southern Economics Association Conference, November 1989.

Raimondo, Henry, Esposito, Louis and Gershenberg, Irving, "Introductory Class Size and Student Performance in Intermediate Theory Courses," Journal of Economic Education, Fall 1990, 21, 369-81.

Saunders, Phillip, "Does High School Economics Have A Lasting Impact?," Journal of Economic Education, Fall 1970, 1, $39-55$.

, "The Lasting Effects of Introductory Economics Courses," Journal of Economic Education, Winter 1980, 12, 1-14.

Siegfried, John and Fels, Rendigs, "Research on Teaching College Economics: A Survey," Journal of Economic Literature, September 1979, 17, 923-69.

and Raymond, Jennie, "A Profile of Senior Economics Majors in the United States," American Economic Review Pro- 
ceedings, May 1984, 74, 19-25.

Watts, Michael and Lynch, Gerald, "The Principles Courses Revisited," American Economic Review Proceedings, May 1989, 78, 263-68.

Williams, David et al., "University Class Size:
Is Small Better?," Research in Higher Education, No. 3, 1985, 23, 307-17.

Yates, Judith, "Research in Economic Education: Are Our Horizons Too Narrow?," Journal of Economic Education, Fall 1978, 10, 12-17. 